\begin{tabular}{|c|c|c|}
\hline $\bar{J}$ & $\begin{array}{l}\text { International Journal of Current Research in } \\
\text { Biosciences and Plant Biology }\end{array}$ & $\frac{1}{2 \sqrt{2+1}}$ \\
\hline $\begin{array}{l}\text { EXCELLENT } \\
\text { PUBLISHERS }\end{array}$ & $\begin{array}{c}\text { Volume } 5 \bullet \text { Number } 1 \text { (January-2018) • ISSN: 2349-8080 (Online) } \\
\text { Journal homepage: } \underline{\text { www.ijcrbp.com }}\end{array}$ & (j) \\
\hline
\end{tabular}

\title{
Effect of Shade at Agrisilviculture System on Characteristics of Stomatal Abaxial Leaf Surfaces in Toraja Highland, Indonesia
}

\author{
Resti Ura'1*, Samuel Arung Paembonan $^{2}$ and Daud Malamassam ${ }^{2}$ \\ 1Postgraduate, Faculty of Forestry, Hasanuddin University, Makassar 90245, Indonesia \\ ${ }^{2}$ Faculty of Forestry, Hasanuddin University, Makassar 90245, Indonesia
}

*Corresponding author.

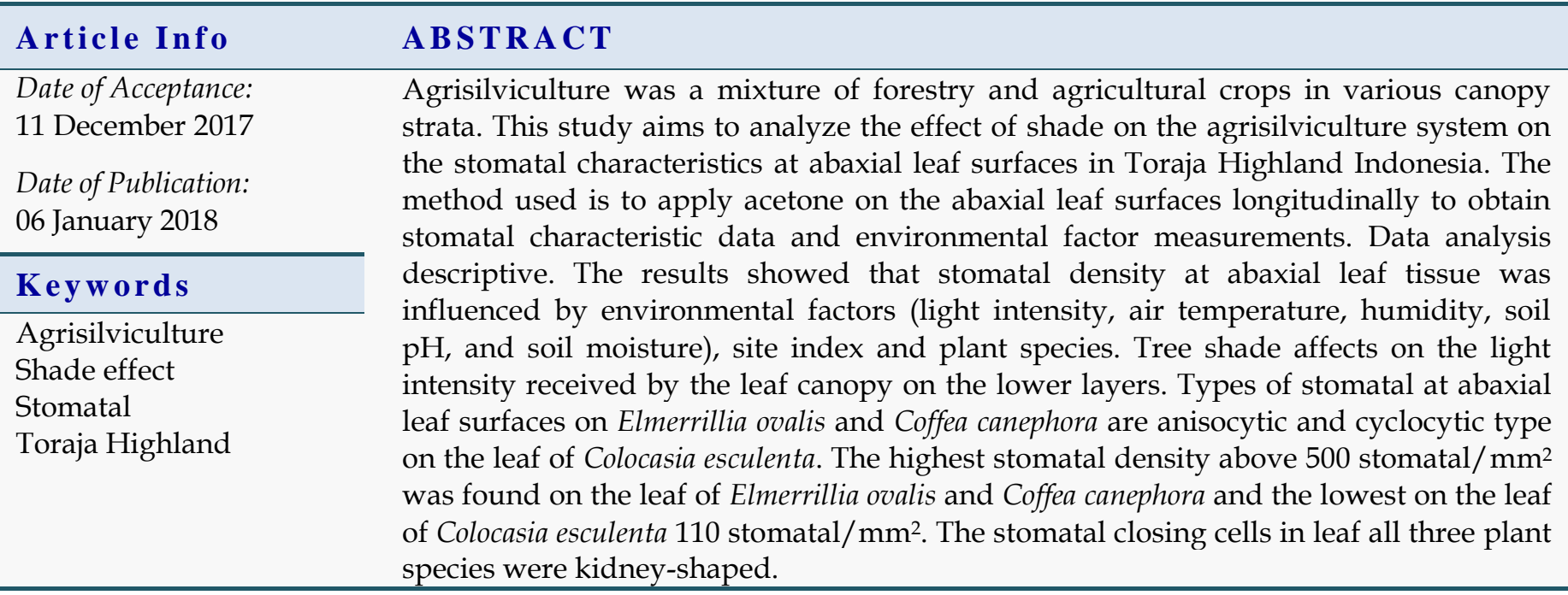

\section{Introduction}

The agrisilviculture system was a dynamic and ecologically-based natural resource management system that combines tree species on a land where the system not only provides socio-economic benefits to farmers, but also provides its own environmental benefits. Tolerance of a tree species to produce under shade with environmental factors where it grows such as light, water, temperature, humidity, soil $\mathrm{pH}$, soil moisture, wind, and nutrients (Zwieniecki et al., 2016; Tambaru, 2012; Salisbury and Ross, 1992). The ability of a tree species to carry out the process of photosynthesis in the absorption of sunlight and water under shade was used as a measure of the relative tolerance of the plant (Santrucek et al., 2014). Tree plays a very important role in nature because it can reduce $\mathrm{CO}_{2}$ gas in the air and produce $\mathrm{O}_{2}$ in the process of photosynthesis (Hoshika et al., 2013; Watanabe et 
al., 2010; Fitter and Hay, 1981). Carbon dioxide plays a very important role for photosynthesis in plants, this was influenced by the concentration, if too high concentration, then stomatal close (Beerling, 2017; Kim et al., 2013; Wardhana, 2004; Larcher, 1995). The endurance of each tree species to grow is also influenced by several factors such as: leaf morphology, leaf anatomy, stomatal density, stomatal size, and stomatal location on leaf surface. The high density of stomatal at abaxial leaf surfaces was a process of adaptation of plants to environmental conditions (Campbell et al., 2003).

Sereale District is located in the highland of North Toraja Regency South Sulawesi, Indonesia, which located at an altitude of $\pm 750-2604 \mathrm{~m}$ above sea level. North Toraja is one of rural areas that have a diversity of flora that has not been much studied (Tambaru, 2012). Based on the above description, we conducted a study on the effect of shade at agrisilviculture system on characteristics of stomatal abaxial leaf surfaces.

\section{Materials and methods}

Plant materials used in this study were: Elmerrillia ovalis, Coffea canephora and Colocasia esculenta. Chemicals used acetone to make stomatal leaves.

Leaf measurements and observations included leaf morphology, stomatal type characteristics, stomatal size, stomatal index, the number of stomatal, and number of epidermis cells in Agrisilviculture plants. Analysis of longitudinal stomatal characteristics of leaf plants on the surface of the lower leaves (abaxial) smeared with acetone on leaves still in the tree. The dried stomatal mold is then covered with clear tape and then drawn and placed on top of the glass object. Stomatal preparations are observed under a microscope with 200x magnification. observations of leaf anatomical characters include the number of stomatal, epidermis cells and stomatal index. Observation of length, width, stomatal opening, and stomatal type using 400x magnification. Samples were then photographed using Bino Microscope and Photo model DS.Fi I Nikon ECLIPSE 80i with 400x magnification. The calculation of Stomatal Index (SI) based on the formula (Sunarti et al., 2008; Damayanti, 2007 cit. Tambaru, 2015; Santrucek et al., 2014; Obembe, 2015) was as follows:

$$
\mathrm{SI} \%=\frac{\mathrm{S} / \mathrm{L}}{(\mathrm{S}+\mathrm{E}) \mathrm{L}} \times 100 \%
$$

Where,

$\mathrm{S}=$ number of stomatal; $\mathrm{E}=$ number of epidermis cells; $\mathrm{L}=$ unit leaf area

Environmental factors that influence plant growth were measured are light intensity (light meter model LX-130), temperature and humidity (thermometer/hygrometer). Measurements done at $10 \mathrm{am}$ at the time of sunlight intensity in optimal state. In addition, measurements were also done on $\mathrm{pH}$ and soil moisture (soil tester model DM-5).

\section{Results and discussion}

Description of plant species in the agrisilviculture system in Sereale North Toraja are:

\section{a. Elmerrillia ovalis (Miq.) Dandy}

Habitus is a tree, tap root system, round stem, the direction of growing stem was erectus, monopodial branching, branch skew up (patens), single leaf spread, elongated leaf shape, pinnate leaves, flat leaf edge, pointed leaf tip, base of pointed leaves, green leaf color, chartaceus leaf meat, leaf surface wrinkled. The shape of the canopy of Elmerrillia ovalis is pyramidal, including Classis Dicotyledoneae and Family Magnoliaceae.

\section{b. Robusta Coffee Coffeacanephora Pierre ex Froehner var. robusta}

Shrub habit, tap root system, round stem, the direction of growing stems is erectus, sympodial branching, direction of growing branches was drooping (declinatus), single leaf lying opposite, oval leaf shape, pinnate leaves, leaf edges, leaf meat like paper, pointed leaf tip, base of leaves roundeddull, slick shiny surface of the leaf, the color of the 
leaves on the upper surface was dark green and lower light green. The shape of the canopy of Coffeaca nephora was semi-globular included in the Class Dicotyledoneae and Family Rubiaceae.

\section{c. Taro Colocasia esculenta (L.) Schott.}

Habitus herbs-shrubs, fiber root system, stem/ stems tuber are in the soil, the direction of growing stems is erectus. Root rosette was the leaves grow near the surface of the land. Single leaf, leaf shape in the form of a shield (peltatus), leaf edges, pointed leaf tip, leaf base grooved, palminerved leaves. Upper leaf surface was slippery and coated with wax, leaves are green, leaf meat was soft and contains water. The shape of the canopy of Colocasia esculenta was semi-globular, included in the Class Monocotyledoneae and Family Araceae.

The result of data analysis characteristic of stomatal at abaxial leaf surfaces the longitudinal cross section from the study of the shade effect on the agrisilviculture system in Sereale North Toraja was shown in Table 1 and Figs. 1-4.

The results of the study in Table 1 and Fig. 1 show the type stomatal at abaxial leaf surfaces Elmerrillia ovalis and Coffea canephora are anisocytic. Type anisocytic are these stomatal remain encircled by three subsidiary cells of which one was distinctly smaller or large in size than the other two (Chachad and Vaidya, 2016; Sreelakshmi et al., 2014; Mulyani, 2006; Pandey and Chadha, 1996). The irregular stomatal distribution on the leaf surface is a hallmark of Classis Dicotyledoneae (Nugroho et al., 2006). Type stomatal abaxial of Colocasia esculenta was a cyclocytic type with four or more subsidiary cells arranged in a closed ring around the stoma. The cyclocytic type was a regular dispersal of stomatal in a longitudinal series characteristic of Class Monocotyledoneae (Nugroho et al., 2006; Pandey and Chadha, 1996).

Table 1. Stomatal characteristics based longitudinal cross-section of leaf on agrisylviculture system in Sereale North Toraja.

\begin{tabular}{llll}
\hline Characteristics & Elmerrillia ovalis & Coffea canephora & Colocasia esculenta \\
\hline Location I: & & & \\
Stomatal type & Anisocytic & Anisocytic & Cyclocytic \\
The spread of stomatal & Irregular & Irregular & Arranged longitudinally \\
Cell shape of closing stomatal & Kidney-shaped & Kidney-shaped & Kidney-shaped \\
Stomatal length $(\mu \mathrm{m})$ & 24.00 & $14.4-28.80$ & $19.20-26.40$ \\
Stomatal width $(\mu \mathrm{m})$ & $26.40-28.80$ & $24.00-36.00$ & $21.60-26.40$ \\
Stomatal opening $(\mu \mathrm{m})$ & $10.20-12.00$ & $7.20-12.00$ & $7.20-7.80$ \\
Stomatal size $(\mu \mathrm{m})$ & $500.54-546.40$ & $273.02-819.07$ & $400.44-550.60$ \\
Stomatal index $(\%)$ & $30.999-38.567$ & $20.095-27.273$ & $5.237-7.469$ \\
Stomatal density $\left(\mathrm{mm}^{2}\right)$ & $772-1012$ & $416-612$ & $68-84$ \\
Number of epidermis cells $\left(\mathrm{mm}^{2}\right)$ & $1612-2128$ & $1532-2020$ & $892-1520$ \\
\hline Location II: & & & \\
Type Stomatal & Anisocytic & Anisocytic & Cyclocytic \\
The spread of stomatal & Irregular & Irregular & Arranged longitudinally \\
Cell shape of closing stomatal & Kidney-shaped & Kidney-shaped & Kidney-shaped \\
Stomatal long $(\mu \mathrm{m})$ & $24.00-33.60$ & $24.00-31.20$ & $28.80-40.80$ \\
Stomatal width $(\mu \mathrm{m})$ & $24.00-33.60$ & $33.60-36.00$ & $28.80-33.60$ \\
Stomatal opening $(\mu \mathrm{m})$ & $8.40-12.00$ & $9.60-13.20$ & $6.60-17.40$ \\
Stomatal size $(\mu \mathrm{m})$ & $637.06-700.76$ & $682.56-828.17$ & $764.47-1083.00$ \\
Stomatal index $(\%)$ & $36.949-38.361$ & $21.208-26.695$ & $5.398-12.308$ \\
Stomatal density $\left(\mathrm{mm}{ }^{2}\right)$ & $804-936$ & $504-632$ & $84.00-256.00$ \\
Number of epidermis cells $\left(\mathrm{mm}^{2}\right)$ & $1372-1548$ & $1384-2348$ & $1472-1824$ \\
\hline Description: Location I in Pongmela Sereale and Location II in Buntu Sereale North Toraja.
\end{tabular}




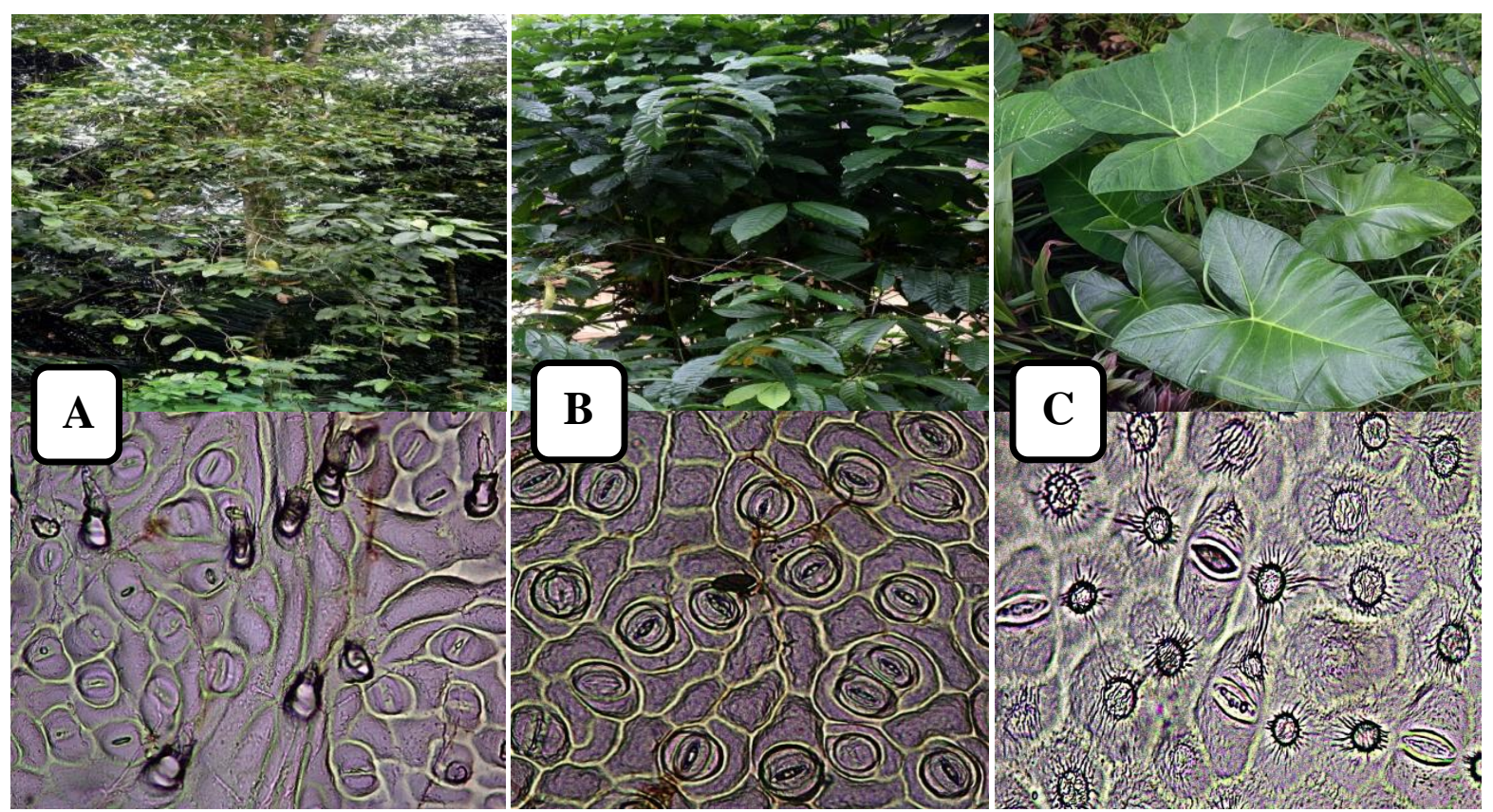

Fig. 1: Plant morphology and stomatal magnification (400x): (A) Elmerrillia ovalis, (B) Coffea canephora,

(C) Colocasia esculenta.

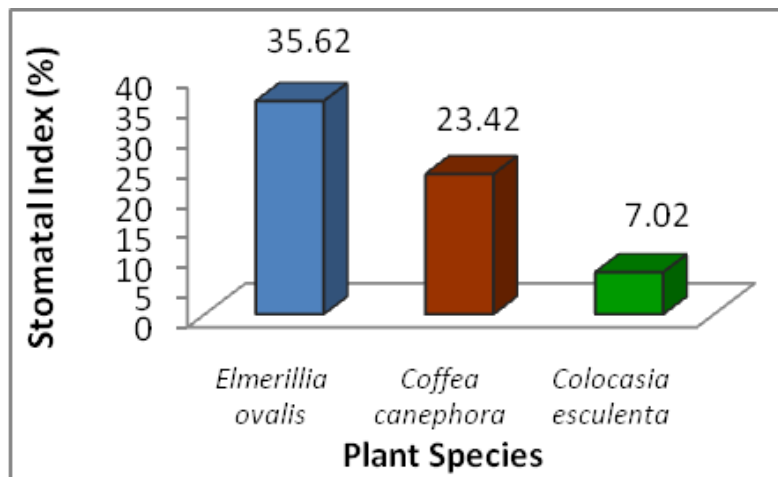

A

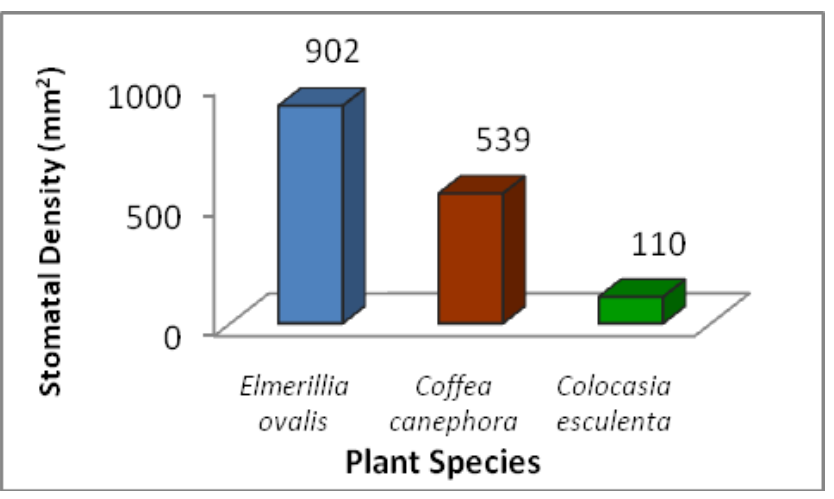

B

Fig. 2: A. Histogram of average stomatal index (\%); B. Histogram of average stomatal density $\left(\mathrm{mm}^{2}\right)$.

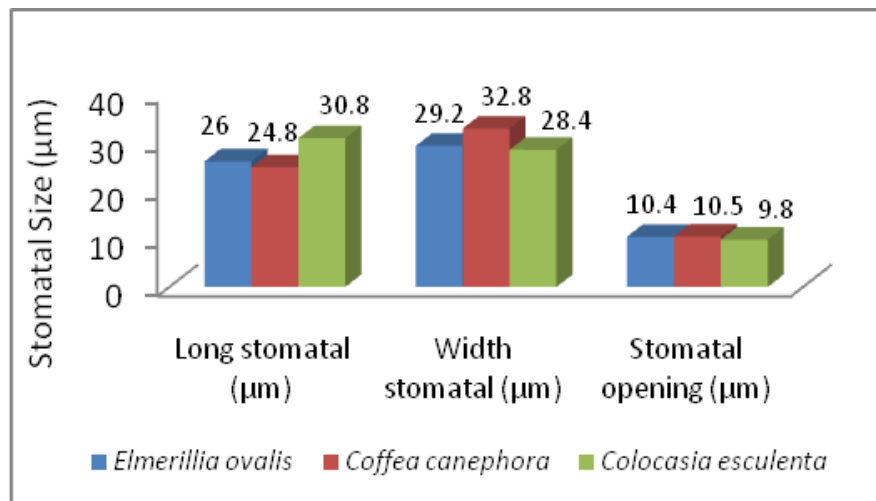

A

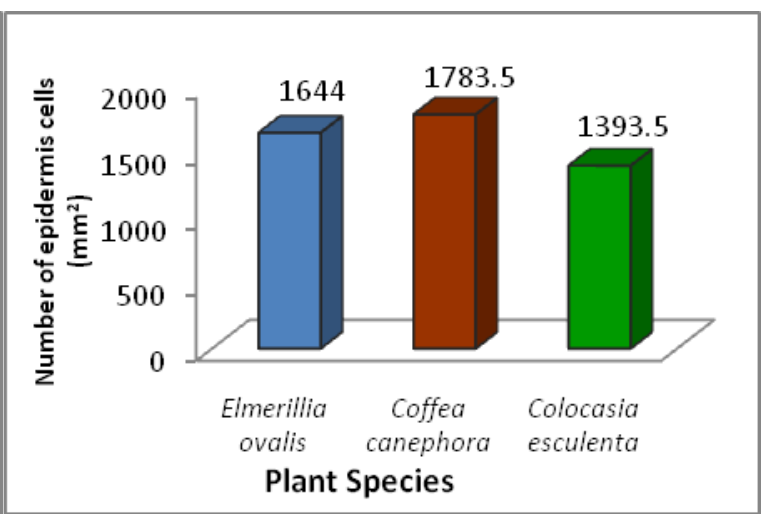

B

Fig. 3: A. Histogram of average number of epidermis cells $\left(\mathrm{mm}^{2}\right)$; B. Histogram of average stomatal size $(\mu \mathrm{m})$. The average stomatal index in Fig. 2A shows the highest stomatal index found on Elmerrillia ovalis 
leaves $35.62 \%$ and the lowest on the leaves of Colocasia esculenta $7.02 \%$. The density of stomatal at abaxial leaf surfaces in Fig. 2B shows that in Elmerrillia ovalis averages of 902 stomatal $/ \mathrm{mm}^{2}$ and the average Coffea canephora 539 stomatal $/ \mathrm{mm}^{2}$ including high stomatal density amounts as the amount above $500 \mathrm{stomatal} / \mathrm{mm}^{2}$. At Colocasia esculenta the averages 110 stomatal $/ \mathrm{mm}^{2}$, including low stomatal density for less than 300 stomatal $/ \mathrm{mm}^{2}$ (Tambaru, 2017). The stomatal closing cells in all three plant species were kidney-shaped (Mulyani, 2006; Pandey and Chadha, 1996).

The results of the study in Fig. 3A show the highest average number of epidermis cells found in the Coffea canephora 1783.5 epidermis cells $/ \mathrm{mm}^{2}$ and the lowest in the Colocasia esculenta 1393.5 epidermis cells $/ \mathrm{mm}^{2}$. The result of stomatal size at abaxialin Fig. 3B shows that the longest average stomatal in Colocasia esculenta is $30.8 \mu \mathrm{m}$ and the shortest Coffea canephora is $24.5 \mu \mathrm{m}$. The widest stomatal of Coffea canephora is $32.8 \mu \mathrm{m}$ and is narrower in Colocasia esculenta $28.4 \mu \mathrm{m}$. The largest stomatal opening of Coffea canephora 10.5 $\mu \mathrm{m}$ and Colocasia esculenta $9.8 \mu \mathrm{m}$. According to Hidayat (2009) cit. Tambaru, (2017), that the stomatal size is said to be less long $(<20 \mu \mathrm{m})$, long (20-25 $\mu \mathrm{m})$ and very long $(>25 \mu \mathrm{m})$. Where large stomatal actually gave low stomatal density and small stomatal gave high density in some plant species (Tambaru, 2012; AbdulRahaman and Oladele, 2003). Stomatal density of abaxial leaves more than the leaf of adaxial, this was a mechanism of plant adaptation to terrestrial environmental conditions (Campbell et al., 2003), to reduce transpiration on the leaf surface (Kumekawa et al., 2013; Larcher, 1995; Salisbury and Ross, 1992). According to Nugroho et al. (2006), there are two types of leaves on the plant is dorsiventral leaves usually grow horizontally, on the top of the leaf surface the color is brighter than the lower leaf surface was found in Class Dicotyledoneae. Type of leaf isobilateral if the leaves grow vertically, so both sides of the leaf surface receive sunlight with the same intensity found in Classis Monocotyledoneae. The results of Tambaru (2012) show that the decrease in the number of stomatal can be influenced by the location where it grows, the type of plants and environmental factors.

Salisburry and Ross (1992), Fitter and Hay (1981) stated that the leaves exposed to full sunlight have a narrow leaf surface area and thick, while the leaves are shaded leaf size was wider and thinner.Leaves in shaded plants have the ability to absorb far-redlight with a $700 \mu \mathrm{m}$ wavelength, the leaves contain a lot of chlorophyll b. Sun exposed leaves can directly absorb red-light wavelength $680 \mu \mathrm{m}$ from leaves containing chlorophyll a (Tambaru, 2012; Salisburry and Ross, 1992).

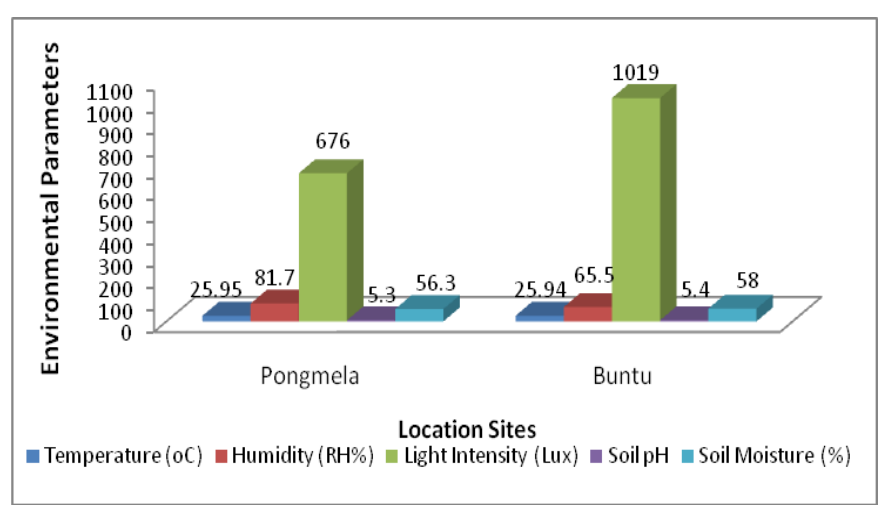

Fig. 4: Histogram of average comparisons of environmental parameters at research sites shade trees in Sereale North Toraja, Indonesia.

The result of environmental factor measurement in Figure 4 at 2 research sites, I Pongmela location: temperature $25.95^{\circ} \mathrm{C}$, humidity $81.7 \mathrm{RH} \%$, soil $\mathrm{pH}$ 5.3, and light intensity 676 lux. Location II Buntu: temperature $25.94^{\circ} \mathrm{C}$, humidity $65.5 \mathrm{RH} \%$, soil $\mathrm{pH}$ 5.4, and light intensity 1019 lux. The results of this study indicate that the density of stomatal was influenced by environmental factors such as: the intensity of sunlight, temperature, humidity, and soil $\mathrm{pH}$, site index and plant species. Tree shade affects the intensity of sunlight received on the leaf canopy in the lower layers, thus affecting the activity of plant photosynthesis. Each type of plant has a different response to the high and low intensity of light for photosynthesis activity (Wijayanto and Aziz, 2013). According to Holland and Richardson (2009), there is an increase in stomatal density based on altitude, especially in 
mountain areas.

The research location in Sereale, North Toraja was a mountainous area that has a diversity of flora with cold environmental conditions and high humidity conditions are very favorable for the growth of plants, especially Elmerrillia ovalis, Coffea canephora and Colocasia esculenta. This type of plant also has more stomatal in abaxial leaf surfaces, potentially absorbing more carbon dioxide from the environment.

\section{Conclusion}

Stomatal density of abaxial leaf surfaces was influenced by environmental factors (sunlight intensity, air temperature, soil moisture $\mathrm{pH}$, and soil moisture), site index and plant species. Tree shade affects the intensity of sunlight received by the leaf canopy on the lower layers. The stomatal types at abaxial leaf surfaces on Elmerrillia ovalis and Coffeaca nephora are: anisocytic and cyclocytic type on the leaf of Colocasia esculenta. The highest stomatal density above 500 stomatal $/ \mathrm{mm}^{2}$ was found on Elmerrillia ovalis and Coffea canephora leaf and the lowest $110 \mathrm{stomatal} / \mathrm{mm}^{2}$ on Colocasia esculenta leaf. The stomatal closing cells in leaf of all the three plant species were kidney-shaped.

\section{Conflict of interest statement}

Authors declare that they have no conflict of interest.

\section{Acknowledgement}

The authors would like to thank the Regent of North Toraja, South Sulawesi, Indonesia; Head of District Sereale and Limbong Kanan Villagers for their support and assistance in this research.

\section{References}

Abdul Rahaman, A.A., Oladele, F.A., 2003. Stomatal complex types, stomatal size, density and index in some vegetable species in Nigeria. Nig. J. Bot. 16, 144-150.
Beerling, D.J., 2017. Gas valves, forests and global change: A commentary on Jarvis (1976) the interpretation of the variation in leaf water potential and stomatal conductance found in canopies in the field. Phil. Trans. R.Soc. B. 370, 20140311, The Royal Society Publishing, pp.19.

Campbell, N.A., Reece, J.B., Mitchell, L.G., 2003. Biology. $5^{\text {th }}$ Edn., Volume 2. The Publisher Erlangga, Jakarta. pp.309-310.

Chachad, D.P., Vadya, M., 2016. Stomatal studies of some selected plants of Malvaceae. World J. Pharmaceut. Res. 5(3), 1060-1068.

Fitter, A.H., Hay, R.K.M., 1981. Environmental Physiology of Plants. Published by Arrangement with Academic Press, Inc., (London) Ltd., 421p.

Holland, N., Richardon, A. D., 2009. Stomatal length correlates with elevation of growth in four temperate species. J. Sustain. For. 28, 6373.

Hoshika, Y., Omasa, K., Paoletti, E., 2013. Bothzone exposure and soil water stressre able to induce somatal sluggishnes. Environ. Exp. Bot. 88, 19-23.

Kim, K.W., Oh, C.Y., Lee, J.C., Lee, S., Kim, P.G., 2013. Alteration leaf surface structures of poplars under elevated air temperature and carbon dioxide concentration. Appl. Microscopy. 43(3), 110-116.

Kumekawa, Y., Miyata, H., Ohga, K., Hayakawa, H., Yokoyama, J., Ito, K., Tebayashi, S.I., Arakawa, R., Fukuda, T., 2013. Comparative analyses of stomatal size and density among ecotypes of Aster hispidus (Asteraceae). Amer. J. Plant Sci. 4, 524-527.

Larcher, W., 1995. Physiological Plant Ecology Ecophysiology and Stress Physiology of Functional Groups. $3^{\text {rd }}$ Edn. Springer-Verlag Berlin Heidelberg, Printed in Berlin. 506p.

Mulyani, E.S., 2006. Anatomy of Plants. The Publishers Kanisius, Yogyakarta. 325p.

Nugroho, L.H., Purnomo, Sumardi, I., 2006. Structure and development of plants. Publishers Peneber, Jakarta. pp.84-119.

Obembe, O.A., 2015. Structural diversity of stomata in some Monocotyledonous weeds. 
World J. Sci. Technol. Res. 3(1), 1-13.

Pandey, S.N. Chandha, A., 1996. A Texbook of Botany Plant Anatomy and Economic Botany Volume III. Vikas Publishing House Pvt. Ltd., New Delhi. pp.101-103.

Salisbury, F.B., Ross, C.W., 1992. Plant Physiology. Wardsworth Publishing Company Belmont California. 682p.

Santrucek, J., Vrablova, M., Simkova, M., Hronkova, M., Drtinova, M., Kveton, J., Vrabl, D., Kubasek, J., Mackova, J., Wiesnerova, D., Neuwithova, J., Schreiber, L., 2014. Stomatal and pavement cell densiy linked to leaf internal $\mathrm{CO}_{2}$ concentration. Ann. Bot. 114, 191-202.

Sreelakshmi, V.V., Sruthy, E.P.M., Shereena, J., 2014. Relationship between the leaf and taxonoic importance of foliar stomata. Int. J. Res. Appl. Natural Soc. Sci. 2(7), 53-60.

Sunarti, S., Rugayah, Tihurun, E.F., 2008. Study of anatomy leaf types Averrhoa in Indonesia to reinforce the taxonomic status. News Biol. 9(3), 253-257.

Tambaru, E., 2012. The Biodiversity and Potential of Some Bamboo Species in Sereale District, North Toraja Regency, South Sulawesi, Indonesia. Wallace Darwin Science Symposium 2012- Understanding and Suistaning the Biodiversity and Ecosystem for-Well Being, ISBN: 978-602-8405-47-8. pp.14-22.

Tambaru, E., 2012. The Potential of Carbon
Dioxide in Some Tree Species in the Urban Forest of Makassar City. Disertation Hasanuddin University, Makassar. pp.128-146.

Tambaru, E., 2015. Identification of morphology and stomatal leaves anatomy of Flacourtia inermis Roxb. J. Natural Environ. Sci. 6(11), 37-41.

Tambaru, E., 2017. Comparative analysis of stomatal type of Swietenia macrophylla King and Polyalthia longifolia Bent and Hook. var. pendula in Makassar, South Sulawesi Indonesia. Int. J. Curr. Res. Aca. Rev. 5(3), 3134.

Wardhana, W. A., 2004. Impact of Environmental Pollution. The Publishers Andi Yogyakarta. 459p.

Watanabe,Y., Tobita, H., Kitao, M., Maruyama, Y., Choi, D., Sasa, K., Funaada, R., Koike, T., 2008. Effects of elevated $\mathrm{CO}_{2}$ and nitrogen on wood structure related to water transport in seedling of two deciduous broad-leaved tree species. Trees. 22, 403-411.

Wijayanto, N., Azis, S.N., 2013. Shading influence of Sengon Falcataria moluccana L. and fertilization against white ganyong growth (Canna edulis Ker). J. Silvicult. Trop. 4(2), 62-68.

Zwieniecki, M.A., Haaning, K.S., Boyce, C.K., Jensen, K.H., 2016. Stomatal design principles in synthetic and real leaves. J. Royal Soc. Interface. 13, 1-7.

\section{How to cite this article:}

Resti Ura', Paembonan, S. A., Malamassam, D., 2018. Effect of shade at agrisilviculture system on characteristics of stomatal abaxial leaf surfaces in Toraja Highland, Indonesia. Int. J. Curr. Res. Biosci. Plant Biol. 5(1), 18-24. doi: https://doi.org/10.20546/ijcrbp.2018.501.003 